\title{
REPRESENTASI KESADARAN AGENSI MORAL SEBAGAI GURU: STUDI FENOMENOLOGI PADA MAHASISWA PASCASARJANA UNIVERSITAS PENDIDIKAN INDONESIA
}

\author{
Teguh Ibrahim, Babang Robandi \\ Sekolah Pascasarjana Universitas Pendidikan Indonesia \\ teguh.ibrahim14@upi.edu
}

\begin{abstract}
Abstrak: Artikel ini bertujuan mendeskripsikan representasi kesadaran agensi moral mahasiswa pascasarjana UPI pada pengalaman atau fenomena profesi guru. Dalam penelitian ini agensi moral dapat dimaknai pada dua kondisi ganda yang melingkupi guru sebagai figur teladan yang melakukan tindakan profesional secara etis dan sebagai pendidik moral yang mengajarkan nilai-nilai kebajikan kepada siswa agar menjadi manusia yang berkarakter. Penelitian ini menggunakan pendekatan kualitatif dengan kerangka fenomenologi. Pengumpulan data menggunakan pedoman wawancara yang dirancang dengan mengacu pada struktur pembangun agensi moral yaitu: identitas moral, sensitivitas moral, dan tindakan moral. Partisipan pada penelitian ini adalah lima orang mahasiswa Program Studi Magister Pedagogik Sekolah Pascasarjana UPI. Hasil penelitian menunjukkan bahwa para Partisipan memaknai guru secara esensial sebagai pekerjaan yang memiliki tanggung jawab moral, dan guru bertanggung jawab atas masa depan peserta didiknya baik secara khusus maupun umum. Partisipan juga menyatakan bahwa guru adalah pahlawan tanpa tanda jasa, mengabdi pada negeri, dan sebuah kebahagian batin ketika bisa melihat peserta didiknya berprestasi. Melalui pembangunan identitas moral, partisipan mampu menghidupkan sensitivitas moral dengan mengidentifikasi beberapa situasi problematis yang menggejala pada realitas kehidupan guru di sekolah. Oleh karena itu, dengan penuh kesadaran, partisipan mampu melakukan tindakan moral untuk mengemansipasi kehidupan profesi guru menjadi lebih baik.
\end{abstract}

Kata kunci: Agensi moral, fenomenologi, pendidikan karakter, berpikir reflektif, profesi guru.

\section{REPRESENTATION OF MORAL AGENCY AWARENESS AS A TEACHER: PHENOMENOLOGICAL STUDY IN POSTGRADUATE STUDENTS IN UNIVERSITAS PENDIDIKAN INDONESIA}

\begin{abstract}
This article aims to describe the representation of the moral awareness of UPI graduate students on the experiences or phenomena of the teacher profession. In this study moral agency can be interpreted in two double conditions which surround the teacher as a role model who takes profesional action ethically and as a moral educator who teaches virtue values to students so that they become human characters. The research uses a qualitative approach with a phenomenological framework. Data collection uses interview guidelines designed with reference to the structure of moral agency building, namely moral identity, moral sensitivity and moral action. Participants in this study were five students of
\end{abstract}


the UPI Postgraduate School's Pedagogic Masters Study Program. The results show that participants interpret the teacher essentially as a job that has moral responsibility, the teacher is responsible for the future of the students specifically and education in general. Participants also stated that being a teacher is an unsung hero, serving the country, and an inner happiness can see their students perform. Through the building of moral identity, participants are able to turn on their moral sensitivity by identifying several problematic situations that affect the reality of the teacher's life at school. So that participants are able to perform moral actions with full awareness to emancipate the profesional life of the teacher for the better.

Keywords: Moral agency, phenomenology, character education, reflective thinking, teacher profession

\section{PENDAHULUAN}

Guru merupakan seorang pedagog (ahli didik) yang berperan sebagai agensi moral, sudah seharusnya sosok guru mampu memantulkan nilai-nilai kebajikan dalam setiap jengkal eksistensinya di dunia pendidikan. Moralitas seorang Guru merupakan persoalan yang sangat sensitif, mengingat setiap perilaku guru dalam menjalani kehidupan profesinya selalu berkaitan dengan usaha memanusiakan manusia. Berkaitan dengan hal tersebut, kondisi eksistensi guru dalam konteks moral belumlah ideal. Temuan Strike \& Ternasky (1995) pendidikan masih belum memiliki "bahasa etika" atau bahasa moral yang mampu membantu guru mengenali mengartikulasikan, dan berkomunikasi dengan guru lain mengenai kompleksitas moral dan etika pengajaran mereka (Colnerud, 2006; Sockett \& LePage, 2002). Lebih jauh lagi Sockett \& LePage (2002) menyoroti kondisi profesi guru yang memprihatinkan karena tidak adanya kosakata moral. Dalam hal ini, mereka mengusulkan bahwa guru membutuhkan semacam "hukum moral" untuk memberikan basis kepercayaan diri dalam membuat penilaian etis yang dapat mengalahkan intuisi.

Temuan yang lebih mutakhir terkait dengan profesi guru dikemukakan oleh Jahan \& Islam. Keduanya menjelaskan:

Almost all scholars emphasize teachers' ethical responsibilities but many university teachers are engaging in unethical behaviour in the form of breaking their commitments to their profession and to students. In curriculum development, classroom teaching, conducting examinations and student evaluation, publishing results, student-teacher interaction, research and publications, teachers have traditionally adopted unfair means whether intentionally or unintentionally (Jahan \& Islam, 2014: 66).

Mengacu pada temuan Jahan \& Islam, dapat disimpulkan bahwa perilaku tidak etis masih cenderung muncul dalam kehidupan profesi guru. Hal ini disebabkan karena kurangnya perhatian pada pembinaan etika profesi guru. Selain itu dalam perspektif Ball (2003) tekanan neoliberalisme pada dunia pendidikan 
telah mengikis identitas profesionalisme guru, orientasi kebijakan pendidikan lebih terpusat pada orientasi pasar, management bisnis, dan performa. Kebijakan ini telah mengubah secara mendalam identitas dan sifat pekerjaan guru sebagai pendidik dan pembimbing (Ball, 2003, Codd, 2005).

Sementara itu Egan, Kayhan, dan Ramirez, (2004: 304) menegaskan bahwa banyak profesi yang menetapkan peraturan, yang meliputi standar penerimaan, kode etik, dan ujian sertifikasi untuk memberikan jaminan bagi masyarakat bahwa profesi ini dikelola dengan serius. Ini berarti menjadi seorang profesional bukan hanya sebuah proses intelektual, melainkan juga sebuah proses sosial dan moral. Bertemali dengan pendapat Egan, Kayhan dan Ramirez, muncul sebuah pertanyaan, apakah guru sudah sepenuhnya menyadari bahwa menjadi seorang profesional harus melibatkan proses intelektual, social, dan moral. Poin yang terakhir acap kali diabaikan oleh para profesional. Menurut teori persepsi diri Fazio (1987) orientasi kuat terhadap moralitas adalah status quo moral. Artinya, guru senantiasa mengadopsi status quo aturan atau moralitas yang ditetapkan oleh pemerintah. Fazio menambahkan bahwa ada tiga kemungkinan ketika seorang profesional terjebak pada status quo moral, (menyesuaikan diri dengan norma-norma, menyimpang secara positif dari norma-norma, menyimpang secara negatif dari norma-norma). Kondisi ini tidak sepenuhnya benar, karena pada dasarnya moralitas seorang guru harus tumbuh dalam diri secara otentik, guru harus menyadari perannya sebagai agensi moral.

Menurut Campbel (2003) agensi moral adalah kondisi ganda yang melingkupi guru sebagai sosok bermoral yang melakukan tindakan profesional etis sekaligus sebagai pendidik moral yang mengajarkan pada siswa kebajikan dan asas inti yang sama dan diperjuangkannya untuk ditegakkan dalam praktik. Lebih jauh lagi Campbel (2008) menegaskan bahwa sebagai agensi moral, guru harus memiliki tingkat kesadaran moral yang tinggi. Dalam hal ini, tingkat kesadaran tertanam ketika guru mengembangkan kapasitas untuk mengidentifikasi bagaimana nilai-nilai dan asas-asas moral serta etika dicontohkan melalui tindakan, ucapan, pengambilan putusan, dan niat mereka sendiri. Hubungan seperti itu tercipta secara intelektual, emosi, intuitif, filsafat, praktik, dan eksperiensial ketika guru melakukan refleksi perseorangan dan diskusi kolektif bersama rekan sejawat perihal pekerjaan yang merka geluti setiap hari.

Bertemali dengan pendapat Campbel, peneliti ingin mengkaji secara fenomenologis kesadaran agensi moral mahasiswa Pedagogik yang berprofesi sebagai guru. Penelitian ini bertujuan mengungkap representasi kesadaran agensi moral mahasiswa program studi Pedagogik Sekolah Pascasarjana UPI tentang profesinya sebagai guru dan pedagog. Tujuan dari penelitian ini diharapkan akan menggambarkan kondisi kesadaran agensi moralpartisipan secara eksplisit, karena pada intinya penelitian fenomeologi berusaha mengangkat makna dari suatu 
pengalaman reflektif individu atau sekelompok orang pada fenomena tertentu. Kesadaran Agensi moral pada penelitian ini dibagi menjadi tiga komponen moralitas profesi yaitu: 1) identitas moral, 2) sensitivitas moral, 4) tindakan moral atau kompetensi (diadopsi dari Rest \& Narvaez, 1994). Tiga komponen tersebut akan diungkap pada wilayah kesadaran partisipan pada pengalamannya sebagai guru sekaligus mahasiswa S2 prodi Pedagogik, perpaduan pengalaman empiris dengan kajian teoretis selama perkuliahan diharapkan akan menghasilkan kajian fenomenologis yang kaya akan profil kesadaran agensi moral mahasiswa pedagogik sebagai seorang guru sekaligus pedagog.

Untuk memaknai konsep agensi moral secara utuh, kita bisa mengawalinya dengan memahami hakikat manusia sebagai makhluk yang otonom, bebas, dan memiliki kesadaran untuk mengatur dirinya sendiri dalam berbagai konteks kehidupan. Karena pada intinya, karakteristik dari 'agensi' hanya dimiliki oleh manusia.

Freire (2001) menegaskan bahwa manusia adalah 'pengada yang menyejarah', penulis menginterpretasi istilah tersebut sebagai kemampuan manusia untuk merangkai jejak eksistensinya dalam kehidupan sosio-kultural secara otonom, manusia memiliki putusan terhadap dirinya sendiri, merefleksikan pengalamannya, dan tentu saja menentukan tujuan hidupnya secara etis. Otonomi manusia mencerminkan kebebasannya dalam berkehendak. Berlin (2014) menganalisis dua konsep kebebasan. Dalam pandangan yang kurang positif, kebebasan atau kemerdekaan disamakan dengan tidak ada intervensi dari pihak lain, manusia dewasa adalah bebas selama mereka tidak dihalangi oleh orang lain, sehingga kebebasan ini cenderung relatif, ambigu dan nonetis. Dalam pandangan yang cukup positif, manusia dikatakan bebas jika mereka mampu menjadi sosok yang seharusnya (normatif), sebuah pribadi yang ideal.

Berdasarkan uraian di atas, dapat dipahami bahwa agensi moral adalah sebuah komponen spiritual dari manusia yang istimewa. Agensi moral adalah otonomi atau kehendak manusia untuk menjadi penyebab, pemegang kontrol dan pencipta laku moral yang senantiasa melakukan kebajikan dan menjauhi keburukan secara sadar, bahkan menjadi agensi moral adalah tujuan hidup dan pola perilaku yang dilakukannya secara tulus dan penuh integritas. Beberapa ahli mendukung definisi tersebut, seperti Bandura (2002: 101) yang menjelaskan:

Moral agency has dual
aspects manifested in
both the power to refrain
from behaving
inhumanely and the
proactive power to
behave humanely. Moral
agency is embedded in a
broader socio-cognitive
self-theory encompassing
affective self-regulatory
mechanisms rooted in
personal standards linked
to self-sanctions.

Sebenarnya satu unsur agensi moral bagi individu mungkin terbukti dalam kecenderungannya untuk 
mempertimbangkan besar atau kecilnya relevansi moral dari tindakannya (Pasupathi \& Wainryb, 2010). Pertimbangan mengenai besarnya relevansi moral dengan tindakan dapat menimbulkan motivasi untuk berbuat kebajikan, sedangkan pertimbangan mengenai kecilnya relevansi moral akan menimbulkan keraguan, kecemasan, malu, atau rasa iba untuk berbuat keburukan yang merugikan atau menyakiti orang lain.

Untuk menentukan apakah sebuah tindakan memiliki relevansi moral memerlukan negosiasi antara individu, dunia sosial dan budaya, serta sifat dari tindakannya (Smetana, 1982; Turiel, Hildebrandt, \& Wainryb, 1991). Karena pada esensinya, nilai moral selalu berdialektika dengan diri, lingkungan sosial, dan budaya yang sudah berkembang. Selain meningkatkan relevansi moral dengan tindakan, agensi moral juga membantu manusia untuk mengontrol hambatan yang sifatnya situasional atau eksternal yang bisa menyebabkan pelepasan moral (Pasupathi \& Wainryb, 2010; Bandura, 2002).

Menurut Taylor (1989), manusia sebagai agensi moral disebabkan karena ia ada dalam ruang pertanyaan moral mengenai apa yang memberi makna dan nilai dalam kehidupan manusia, dan apa artinya menjadi manusia atau orang baik. Selama pencarian makna dan nilai kehidupan, manusia perlu melakukan praktik evaluasi yang kuat terhadap nilai-nilai yang berkembang dalam kehidupan masyarakat, menginterpretasi nilainilai tersebut secara kualitatif, dan mengartikulasikan 'kekayaan konstitutif' secara eksplisit dalam diri. Kekayaan konstitutif adalah cita-cita moral menyeluruh yang memerintahkan untuk mengevaluasi secara kritis nilai-nilai, membingkai komitmen moral, dan mengukuhkan prinsip etika dalam kehidupan secara menyeluruh.

Simpulan yang dapat diambil dari pemikiran Taylor, agensi moral adalah kemampuan manusia untuk menginterpretasi diri, dimulai dari pencarian makna dan nilai-nilai yang penting bagi kehidupan manusia, mengevaluasinya secara kualitatif, mengartikulasikannya dalam bentuk cita-cita moral yang luhur, serta mengaktualisasikannya dalam kehidupan secara konsisten dan menyeluruh. Berdasarkan pendapat para ahli dan peneliti mengenai Agensi Moral dapat diambil sintesis bahwa: dalam berbagai dimensi kehidupan, manusia dihadapkan pada lingkungan sosial yang berpotensi memberikan pengaruh baik atau buruk, pengaruh baik akan menguatkan karakter moral dalam diri manusia, sebaliknya pengaruh buruk berpotensi menimbulkan pelepasan moral dalam diri. Di sinilah proses regulasi diri yang menguatkan agensi moral dibutuhkan, memang tidaklah mudah, tapi perlu usaha yang kuat agar setiap manusia mampu menginterpretasi dirinya sebagai makhluk yang memiliki moralitas untuk mengarungi kehidupan secara etis dan normatif.

\section{METODE}

Penelitian ini menggunakan pendekatan fenomenologi. Fenomena yang akan diteliti pada penelitian ini adalah kesadaran agensi moral partisipan pada pengalaman atau 
fenomena profesi guru. Ruang lingkup agensi moral yaitu identitas moral, sensitivitas moral, dan tindakan moral. Tiga komponen tersebut disadur dari model komponen moralitas profesi yang digagas oleh Rest \& Narvaez (1994). Proses pengumpulan data dimulai dengan melakukan problematisasi pada perkuliahan landasan pendidikan, kemudian secara purposif memilih partisipan untuk diwawancarai lebih dalam lagi.

Tahap analisis data dilakukan dengan membaca transkipsi wawancara. Tahap berikutnya yaitu tahap horizonalisasi (mensejajarkan semua pernyataan, dan mencari pernyataan penting yang relevan dengan penelitian). Pada tahap ini peneliti menggunakan teknik line by line coding (Corbin \& Strauss, 2008). Tahap terakhir yaitu tahap cluster of meaning.

\section{HASIL DAN PEMBAHASAN Hasil}

Penelitian ini memiliki tujuan pedagogis untuk merepresentasikan pengalaman mahasiswa pedagogik dalam menghayati kehidupan profesinya sebagai guru sekaligus sebagai agensi moral. Dalam hemat Campbel (2003), sebagai agensi moral, guru harus memiliki tingkat kesadaran moral yang tinggi. Dalam hal ini, tingkat kesadaran tertanam ketika guru mengembangkan kapasitas untuk mengidentifikasi bagaimana nilai-nilai dan asas-asal moral serta etika dicontohkan melalui tindakan, ucapan, pengambilan putusan, dan niatnya sendiri. Hubungan seperti itu tercipta secara intelektual, emosi, intuitif, filsafat, praktik, dan eksperiensial ketika guru melakukan refleksi perseorangan dan diskusi kolektif bersama rekan sejawat perihal pekerjaan yang dia geluti setiap hari.

Agensi Moral dalam penelitian ini memiliki beberapa komponen atau indikator yaitu identitas moral, sensitivitas moral, dan tindakan moral sebagai agensi. Ketiga indikator dari agensi moral tersebut akan dideskripsikan secara dialektik antara pernyataan verbal partisipan dan teori-teori agensi moral yang relevan. Deskripsi akan disajikan per-indikator, tujuannya adalah agar profil kesadaran agensi moral tampil secara utuh dan mewakili kelima partisipan yang sudah diwawancarai. Adapun deskripsinya adalah sebagai berikut.

\section{Identitas Moral}

Batu pertama yang membangun kesadaran agensi moral adalah identitas moral. "Identitas moral adalah sejauhmana seseorang menganggap bahwa menjadi pribadi yang bermoral merupakan identitas yang dianggap penting bagi dirinya" (Hardy \& Carlo, 2011). Identitas moral adalah bagian dari identitas diri (Bergman, 2004), identitas moral terdiri atas dua aspek, yaitu internalisasi dan simbolisasi (Aquino \& Reed, 2002). Internalisasi menunjuk pada sejauhmana karakteristik moral tertentu penting bagi kehidupan seseorang, sedangkan simbolisasi menunjuk pada sejauhmana karakteristik moral tersebut diimplikasikan terhadap keidupan sehari-hari.

Mengacu pada pendapat para ahli tersebut, maka pada bagian ini peneliti akan mendeskripsikan represantasi kesadaran agensi moral 
para partisipan yang dibangun oleh kesadaran moral sebagai seorang guru. Makna menjadi guru dan pengalaman yang diperoleh sebagai seorang guru. Peneliti akan memulai dengan menyajikan table 1 tentang identitas moral yang diperoleh sebagai berikut.

Tabel 1. Representasi Identitas Moral

\begin{tabular}{|c|c|c|}
\hline Partisipan & $\begin{array}{l}\text { Tema Makna } \\
\text { Guru }\end{array}$ & Deskripsi Fenomenologis \\
\hline Putri & $\begin{array}{l}\text { Guru bukan } \\
\text { sekedar uang, } \\
\text { tapi lebih pada } \\
\text { kepuasan batin }\end{array}$ & $\begin{array}{l}\text { Masalah gaji hanyalah masalah biasa. Kalau ingin gajinya } \\
\text { besar jangan menjadi guru. Ada kepuasan ketika menjadi } \\
\text { guru, yaitu ketika siswa yang tadinya nakal menjadi baik, dari } \\
\text { yang tidak bisa menajdi bisa. Inilah kepuasaannya yang lebih } \\
\text { dari diberi uang yang banyak. Jadi, ada kepuasan batin bagi } \\
\text { guru, terutama ketika siswa karakternya menjadi baik. }\end{array}$ \\
\hline Andri & $\begin{array}{l}\text { Guru memiliki } \\
\text { tanggung jawab } \\
\text { moral dalam } \\
\text { semua dimensi } \\
\text { kehidupan }\end{array}$ & $\begin{array}{l}\text { Seorang guru harus siap dengan tanggung jawab moral. } \\
\text { Menurut saya, ketika berbicara tanggung jawab moral, hal itu } \\
\text { tidak hanya ketika mengajar atau ketika di sekolah, pun ketika } \\
\text { di luar sekolah. Karena, apa yang saya pahami bahwa } \\
\text { tanggung jawab moral tidak terbatas pada satu tempat atau } \\
\text { satu wilayah tertentu. Ketika kita memutuskan untuk menjadi } \\
\text { pendidik atau guru, kita harus bertanggung jawab secara } \\
\text { moral ke semua ranah, yakni pada semua segi kehidupan } \\
\text { kita. }\end{array}$ \\
\hline Cici & $\begin{array}{l}\text { Tugas guru } \\
\text { adalah mengantarkan } \\
\text { menak pada } \\
\text { anak perubahan } \\
\text { positif }\end{array}$ & $\begin{array}{l}\text { Tanggung jawab guru tidak hanya tentang pengajaran atau } \\
\text { mentransfer ilmu saja, tetapi bagaimana saya menyampaikan } \\
\text { ilmu dan menjadikan anak melakukan perubahan ke arah } \\
\text { yang positif. Ketika saya sedang melakukan proses } \\
\text { pembelajaran, apakah anak sudah paham dengan apa yang } \\
\text { saya sampaikan? Apakah dia menerapkannya di kehidupan } \\
\text { sehari-harinya? }\end{array}$ \\
\hline Panrepi & $\begin{array}{l}\text { Guru itu tanpa } \\
\text { tanda jasa }\end{array}$ & $\begin{array}{l}\text { Saya lebih ikhlas menjadi guru bagi anak jalanan dari pada di } \\
\text { sekolah formal. Ada perasaan yang beda ketika bersama } \\
\text { anak-anak jalanan, meskipun tidak ada uangnya. Ketika saya } \\
\text { memberikan ilmu secara suke rala, saya merasa memberikan } \\
\text { semua yang saya miliki. Karena dari kecil saya diberi tahu } \\
\text { bahwa guru adalah pahlawan tanpa tanda jasa. Karena itu, } \\
\text { pada saat saya kuliah di jurusan pendidikan, banyak teman- } \\
\text { teman yang mengeluhkan mengenai gaji guru, tetapi saya } \\
\text { menyadari bahwa guru itu tanpa tanda jasa. }\end{array}$ \\
\hline Meilina & $\begin{array}{l}\text { Guru } \\
\text { mengabdi }\end{array}$ & $\begin{array}{l}\text { Menurut saya, makna guru adalah mengabdi. Guru yang } \\
\text { benar atau membanggakan itu bukan guru yang berprestasi, } \\
\text { tetapi guru yang mengabdi kepada pendidikan dan } \\
\text { mengaktualisasikan dirinya tanpa harus melihat berapa gaji } \\
\text { yang diterimanya. Nilai UKG saya harus seperti ini. Saya bisa } \\
\text { melihat anak-anak nyaman, bahagia, dan tersenyum ketika } \\
\text { mereka itu lulus dan keluar dari SD. }\end{array}$ \\
\hline
\end{tabular}

Representasi Kesadaran Agensi Moral Sebagai Guru: Studi Fenomenologi Pada Mahasiswa Pascasarjana Universitas Pendidikan Indonesia 
Mengacu pada tabel 1 di atas, dapat disimpulkan bahwa para partisipan memaknai guru secara eksistensial sebagai pekerjaan yang memiliki tanggung jawab moral dan berlaku di mana pun guru berada, tidak hanya terpaku di lingkungan sekolah. Tanggung jawab moral terkait dengan masa depan peserta didik secara khusus dan pendidikan secara umum. Selain itu menjadi guru haruslah mengabdi pada negeri, jangan mengharapkan imbalan di awal dan jangan terus-terusan mempermasalahkan tunjangan kesejahteraan, karena hal itu tidak etis. Bagi para partisipan pekerjaan guru adalah kepuasan batin, di saat melihat peserta didik berubah menjadi lebih baik, rasanya sangat senang sekali. Partisipan juga menyatakan bahwa menjadi guru adalah pahlawan tanpa tanda jasa. Simpulan tersebut telah mampu merepresentasikan kesadaran agensi moral yang diawali dengan pembentukan identitas moral. Pada dasarnya identitas moral akan membantu membentuk identitas profesional.

\section{Sensitivitas Moral}

Komponen agensi moral selanjutnya yang akan dibahas adalah sensitivitas moral. Makna dari sensitivitas moral dapat dipahami sebagai kepekaan terhadap situasi tertentu dalam perspektif moral. Narvaez \& Lapsley (2014) menegaskan, "Sensitivity is not the mere ability to see, hear, touch, taste and smell; rather it is a nose for morality, the ability to recognize situations and aspects of situations as morally charged." Artinya, dalam penelitian ini lingkup 'situasi' difokuskan pada situasi diri dalam profesi. Ini melibatkan perasaan (afeksi) tentang pengalaman partisipan menganalisis situasi dilematis yang pernah dijumpai dalam kehidupan profesi guru. Representasi sensitivitas moral dapat dilihat dari tabel 2 berikut ini.

Tabel 2. Sensitivitas Moral Partisipan

\begin{tabular}{|c|c|c|}
\hline Partisipan & Tema & Masalah Profesi Guru \\
\hline Putri & $\begin{array}{lc}\text { Beberapa } & \text { guru } \\
\text { ada yang } & \text { yurang bisa } \\
\text { menjadi teladan }\end{array}$ & $\begin{array}{l}\text { Banyak guru yang kurang dari segi kompetensi kepribadian. Guru } \\
\text { tersebut tidak memberikan teladan yang baik kepada anak-anak. } \\
\text { Misalnya, dalam lingkungan guru, sesama guru harus saling } \\
\text { menghargai, saling menghormati antarsesama profesi guru. Akan } \\
\text { tetapi, ada sebagian guru yang masih sering mengeluarkan kata- } \\
\text { kata yang kurang baik dalam pergaulan di lingkungan profesi, juga } \\
\text { ada yang tidak konsisten anara yang dikatakan dengan yang } \\
\text { dilakukan. }\end{array}$ \\
\hline Andri & $\begin{array}{l}\text { Guru kurang } \\
\text { memiliki tekad } \\
\text { untuk menjadi } \\
\text { guru pembelajar }\end{array}$ & $\begin{array}{l}\text { Saya kadang-kadang merasa prihatin, dari dua sisi. Satu, prihatin } \\
\text { terhadap kinerja guru dan satu lagi, prihatin terhadap beban guru. Ini } \\
\text { saya rasakan, ketika sekarang saya menjadi pengajar. Yang } \\
\text { menjadi keprihatinan saya yaitu tidak banyak atau tidak semua guru } \\
\text { berpikiran untuk menjadi guru pembelajar yang memiliki sifat dan } \\
\text { kompetensi yang sekarang dicanangkan pemerintah. }\end{array}$ \\
\hline
\end{tabular}




\begin{tabular}{lll}
\hline Cici & Banyak guru \\
yang & Kenyataannya, di sekolah keadaan yang ada kurang sesuai dengan \\
mengabaikan & harapan, bukan saya berpandangan negatif, tetapi memang \\
perkembangan & keadaan di sekolah itu kurang ideal. Sebagian kecil guru kondisinya \\
belajar siswa & cukup mengkhawatirkan, seperti adanya guru yang cuek, sehingga \\
& $\begin{array}{l}\text { ketika ada siswa yang salah dibiarkan saja, juga siswa yang kurang } \\
\text { aktif belajar dan kurang kemampuan berpikirnya, siswa tersebut naik }\end{array}$ \\
& kelas terus, tidak pernah tinggal kelas. Pada akhirnya ketika siswa di \\
& kelas 6 diupayakan dengan berbagai cara agar lulus dalam ujian \\
& negara. \\
& Ketika saya ingin melayani siswa yang mengalami kesulitan belajar, \\
& banyak guru yang memberikan saran seperti ini, "Ya jangan peduli, \\
& hiraukan saja itu, jangan focus ke situ, karena kalo focus ke situ \\
& nanti siswa yang lain ketinggalan, dan itu memakan waktu lama, \\
& biarkan saja," kata guru-guru itu kepada saya.
\end{tabular}

\begin{tabular}{|c|c|c|}
\hline Panrepi & $\begin{array}{l}\text { Banyak guru } \\
\text { yang } \\
\text { mengabaikan } \\
\text { pentingnya } \\
\text { pendidikan bagi } \\
\text { anak jalanan }\end{array}$ & $\begin{array}{l}\text { Menjadi guru bagi anak-anak jalanan itu susah, tidak seperti guru } \\
\text { sekolah formal. Susahnya, kita tidak bisa mengubah mindset } \\
\text { mereka. Karena dari basic atau dari lahir, mereka lebih dituntut untuk } \\
\text { mencari uang bukan mencari ilmu oleh orang tua mereka. } \\
\text { Persoalannya, bagaimana cara kita masuk ke lingkungan mereka } \\
\text { tanpa mengubah kewajiban mereka untuk mencari uang. Salah satu } \\
\text { caranya kita memberi sembako kepada mereka, tetapi kendalanya, } \\
\text { ada beberapa anak yang hanya mau datang kalau kita membawa } \\
\text { sesuatu. }\end{array}$ \\
\hline Meilina & $\begin{array}{l}\text { Guru di Daerah } \\
\text { Timur masih } \\
\text { Banyak } \\
\text { melakukan } \\
\text { kekerasan }\end{array}$ & $\begin{array}{l}\text { Mereka (guru) dikatakan sukses mengajar ketika siswa memang } \\
\text { bisa menguasai materi. Tetapi untuk menguasai materi itu anak } \\
\text { harus benar-benar tersiksa lebih dulu. Karena ketika mereka } \\
\text { tersiksa, mereka akan kapok, dan setelah kapok mereka akan ingat. } \\
\text { Ketika situasinya seperti ini, guru terlihat seperti penjajah. } \\
\text { Ketika saya tanya, mengapa mereka seperti itu kepada anak, selalu } \\
\text { ada kekerasan setiap melakukan pembelajaran, atau ketika nilai } \\
\text { siswa tidak memuaskan terus langsung dihantam dengan rotan? } \\
\text { Jawab mereka, "Karena hal itu sudah menjadi tradisi!" Ya, itu } \\
\text { namanya, ada sifat pendidikan yang turun-temurun. }\end{array}$ \\
\hline
\end{tabular}

Mengacu pada tabel 2 di atas, pada intinya partisipan mampu menganalisis beberapa situasi problematis dalam kehidupan profesi guru, situasi tersebut bisa berasal dari kepribadian guru, cara guru memperlakukan siswa, dan kinerja guru secara umum. Menurut partisipan situasi problematis pada kehidupan guru bisa muncul apabila guru tidak bisa berperan sebagai teladan, perilaku kurang etis, dan tidak patut dilihat, apalagi dicontoh.
Partisipan memaparkan ada sebagian kecil guru yang kurang memiliki etika dalam menggunakan bahasa untuk berinteraksi, baik dengan teman sejawat maupun dengan siswa. Partisipan memaparkan, "Saya ketika pernah satu kali melintas di salah satu ruangan belajar, guru itu berkata kepada anak "aaahh kumaha sih teu bisa maneh, belegug" nahh gitu, lalu eeuu ketika itu dengan...dengan superiornya, dengan gagahnya, guru itu memerintah anaknya "coba kamu 
nu teu bisa nangtung" nah gitu kan" (Andri). Bahkan mengacu pada partisipan yang lain, tidak sedikit guru di timur Indonesia yang menggunakan kekerasan dalam proses pembelajaran, "Selalu ada kekerasan setiap pembelajaran ataupun nilai mereka tidak memuaskan terus langsung dihantam dengan rotan ataupun kepalanya dibenturkan ke meja ketika mereka tidak bisa perkalian. Guru-guru yang melakukan kekerasan menjawabnya dengan kalimat "karena itu sudah menjadi tradisi!" (Meilina). Dari paparan tersebut, dapat disimpulkan bahwa masih ada beberapa guru yang masih berkata dan bertindak tidak etis.

\section{Tindakan Moral}

Muara dari representasi kesadaran agensi moral adalah adanya tindakan etis berdaya transformatife. Artinya, para partisipan tidak berdiri sebagai penganut "status quo" atau mereka takut pada otoritas sehingga tidak berani untuk melakukan tindakan perubahan. Mengacu pada hasil interviu, para partisipan pernah melakukan tindakan-tindakan dialogis yang tujuannya adalah mengemansipasi kehidupan sosialnya lebih baik lagi. Representasi agensi moral dalam bentuk tindakan moral dapat dilihat pada tabel 3 beriktu ini.

Tabel 3 Tindakan Moral

\begin{tabular}{|c|c|c|}
\hline Partisipan & Tema & Deskripsi Fenomenologis \\
\hline Putri & $\begin{array}{l}\text { Saya harus } \\
\text { mengubah } \\
\text { semua } \\
\text { kekacauan } \\
\text { ini }\end{array}$ & $\begin{array}{l}\text { Ketika saya masuk kerja di SD ini, begini sekolahnya: sistemnya } \\
\text { kurang ideal, guru-gurunya juga kurang update, anak-anaknya } \\
\text { memprihatinkan. Dari hal itu, saya punya keinginan harus } \\
\text { membenahi sistem di sekolah ini. } \\
\text { Pada saat itu kurikulum } 2013 \text { baru diperkenalkan, baru diterapkan } \\
\text { di sekolah, dan pembelajaran di perkuliahan terakhir masih "anget- } \\
\text { angetnya" kurikulum } 2013 \text {. Apa yang saya pelajari dari Pak } \\
\text { Dharma berbeda dengan yang diterapkan di sekolah, sehingga } \\
\text { harus koordinasi dengan sekolah. Dengan musyawarah dan } \\
\text { kesepakatan akhirnya sekolah menerima masukan dari saya. }\end{array}$ \\
\hline Andri & $\begin{array}{l}\text { Meluruskan } \\
\text { perbuatan } \\
\text { kekerasan } \\
\text { simbolik }\end{array}$ & $\begin{array}{l}\text { Ketika saya melihat ada guru yang melakukan kekerasan simbolik, } \\
\text { saya coba menasihatinya. Saya berkata, "Apakah penyampaian } \\
\text { Bapak tadi bisa dikatakan baik? saya ngeliat Bapak tadi berbicara } \\
\text { "belegug segala macem." } \\
\text { Lalu saya lanjutkan, "Sebenernya gak ada yang "belegug" Bapak!" } \\
\text { Manusia itu makhluk yang selalu cenderung berubah, dari bodoh } \\
\text { bisa menjadi pintar. Jangan dulu mengatakan bahwa murid Bapak } \\
\text { bodoh, mungkin ada faktor yang mempengaruhinya, atau mungkin } \\
\text { cara mengajar bapak yang kurang dipahami siswa. }\end{array}$ \\
\hline
\end{tabular}



Panrepi Tak perlu Ya, menurut saya, sebelumnya pasti ada banyak kejadian. Seperti menyalahkan kejadian "berantem" dan lain sebagainya. Saya suka mengajarkan siapa pun, kepada siswa seperti lebih ke pendidikan sopan santun, moral, dan yang penting menghadap orang tua itu harus dengan hormat.
kita lakukan Tujuannya agar siswa lebih baik. Saya memang tidak bisa yang terbaik mengubah siswa, saya hanya ingin siswa lebih baik saja, seperti di jalan siswa bertatakrama. Saya tidak bisa mengubah anak-anak jalanan yang begitu banyak di Bandung, hanya beberapa saja yang bisa saya ubah.
Saya tidak menyalahkan pemerintah dan siapa saja. Sekarang sudah saatnya kita berbuat apa untuk mewujudkan sesuatu menjadi lebih baik.

Cici Mengajarkan Sebelum ada "gembar-gembor" pendidikan karakter, saya sudah karakter banyak mengajarkan hal-hal itu, tetapi tidak dalam pengajaran dengan tentang jujur ataupun yang baik-baik adalah seperti itu, tetapi cerita dengan cerita. Di awal pembelajaran, saya selalu memberi inspiratif motivasi dengan cerita tokoh atau orang terkenal, atau di kehidupan saya sendiri. Itu pun sebelum perkuliahan dimulai.

Ada siswa yang mengatakan, "Saya ingin menjadi seperti Bu Winda." Jadi, karena kebetulan kos juga di sana, saya memberi tambahan waktu untuk siswa. Setelah pulang sekolah saya berikan les pada siswa secara gratis.

$\begin{array}{lll}\text { Meilina Aku } & \text { Ketika musim hujan, guru-guru di sana paling senang, karena } \\ \text { menjemput } & \begin{array}{l}\text { anak-anak tidak masuk sekolah. Tetapi saya berusaha untuk } \\ \text { muridku } \\ \text { untuk }\end{array} & \begin{array}{l}\text { mengajak mereka sekolah, walaupun hujan. Saya berusaha untuk } \\ \text { sekolah }\end{array} \\ & \begin{array}{l}\text { mengajak mereka sekolah, walaupun hujan turun. Sekalipun hujan } \\ \text { rumah mereka dan saya ajak barena ke sekolah. }\end{array} \\ & \text { Saya melihat ada beberapa guru mengajar dengan cara } \\ & \text { kekerasan. Menurut mereka hal itu sudah menjadi tradisi. Ketika } \\ & \text { saya mengingatkan tentang hal itu saya digerutui. Saya sangat } \\ & \text { tidak setuju pembelajaran seperti itu. } \\ & \text { hal yang seperti itu. Ketika rotan atau harus membenturkan kepala } \\ & \text { ke meja. }\end{array}$

Mengacu pada tabel 3 dapat disimpulkan bahwa partisipan sudah pernah berusaha melakukan tindakan moral dalam rangka mengemansipasi kehidupan profesi mereka, dan memperbaiki ketimpangan sosial di dunia pendidikan sekolah formal maupun nonformal. Beberapa partisipan mengakui pernah bernegoisasi dengan rekan guru yang melakukan tindakan kurang etis dengan cara memberikan nasihat dan analogi. Seperti apa yang telah dilakukan oleh partisipan Andri dan Meilina. Sedangkan partisipan yang lain pernah berinisiatif untuk memberikan bimbingan belajar lebih untuk mengatasi kesulitan belajar siswa, seperti apa yang telah dilakukan partisipan Cici. Partisipan yang lain menuturkan tidak mau menyalahkan siapa pun dan focus pada peningkatan diri sebagai guru. Temuan ini membuktikan bahwa 
partisipan mampu merepresentasikan kesadaran agensi moralnya dalam bentuk tindakan moral. Komponen ini sangatlah penting bagi pembentukan identitas moral.

\section{Pembahasan}

Guru cenderung memiliki identitas profesionalnya yang terbentuk dan dikonsolidasikan pada fase karir awal dengan cara yang memberi dan menyerap tema dan misi pada waktu itu (Hargreaves \& Goodson, 2006; Lasky, 2005). Barrett (2008) berpendapat bahwa identitas profesional memiliki ingatan. Guru dengan karir panjang mengalami reformasi dalam hubungan timbal balik dan bukan dalam isolasi, dan pengenaan yang tidak diinginkan dan dampak kumulatif dari reformasi yang berulang, kontradiktif, dan cepat berlalu cepat menimbulkan banyak kekecewaan. Identitas profesional guru adalah bagaimana guru menentukan dirinya sendiri dan orang lain (Lasky 2005). Perjuangan terus menerus untuk membangun identitas profesional yang berkelanjutan adalah proses yang terus berlanjut dan dinamis yang memerlukan pemahaman dan interpretasi nilai dan pengalaman seseorang (Day, et al., 2006).

Untuk membentuk identitas profesional, guru harus berperan sebagai agensi, seperti temuan Beijaard, Meijer, dan Verloop (2004) yang menegaskan bahwa agensi tersebut adalah elemen penting dari identitas profesional, sementara itu Plasschaert et al. (2002) berpendapat bahwa identitas profesional adalah 'gabungan antara biografi pribadi, budaya, pengaruh sosial dan nilai kelembagaan yang mungkin berubah sesuai peran dan keadaan. Karya Menter (2008) menginformasikan adanya pemeriksaan dimensi kontekstual identitas profesional pada tingkat yang berbeda - tingkat mikro (biografi guru dan interaksinya dengan rekan kerja, siswa dan orang tua dalam konteks tempat kerja langsung), tingkat 'meso' (guru dan sekolahnya), dan 'tingkat makro' (guru sebagai anggota angkatan pengajar dalam konteks sosiokultural yang lebih luas). Mengacu pada pendapat para ahli tersebut, guru dapat mengembangkan kesadaran agensi moral dengan cara memperkuat identitas diri sebagai seorang profesional, atau identitas profesional. Hal ini tentunya melibatkan kemampuan guru dalam membangun aktivitas sosial yang konstruktif di bidang pengajaran dan pendidikan yang lebih luas, sehingga segala aktivitas tersebut terekam dalam jejak biografi kehidupannya sebagai seorang guru profesional.

Terkait dengan sensivitas moral, Freire (2008) menegaskan bahwa ketika guru menyatakan tindakan pelemahan, dalam artian membodohkan siswa, guru terlihat merasa superior, maka secara otomatis siswa posisinya adalah inferior, ini adalah hubungan yang antagonistic, tidak mendidik. Guru yang merasa superior tentu tidaklah etis, apalagi sampai membodohkan atau merendahkan siswa. Dalam hemat Freire (2008) tidak ada dikotomi antara hubungan guru dan siswa, keduanya harus berperan sebagai subjek dalam proses pembelajaran, keduanya adalah pencari ilmu yang dibangun dalam hubungan yang dialektis. 
Ketika guru kurang memiliki etika dalam berkomunikasi dan berinteraksi, maka segala perkataanya tidak bisa digugu dan ditiru. Dalam artian perkataan guru tidak bisa dijadikan teladan. Sedangkan dalam konteks penelitian ini, guru harus berperan sebagai agensi moral. Sedangkan menurut Vargas (2001) dalam sebuah penelitian tentang perkembangan moral guru dan etika profesional dan menunjukkan bahwa perilaku, sikap, nilai, dan prioritas guru merupakan faktor paling kuat untuk menjadi panutan bagi siswa dan juga dalam mentransmisikan nilai ke mereka. Berkali-kali saat menjalankan tugas akademik mereka, guru dan siswa membuat penilaian moral dan mengekspresikan nilai. Biasanya siswa tidak dapat diharapkan untuk menunjukkan tingkat etisitas yang lebih tinggi daripada guru mereka jika hubungan mereka dengan guru mereka kuat.

Partisipan juga menuturkan adanya beberapa guru yang kurang peduli pada perkembangan belajar siswa, guru hanya focus pada siswa yang memiliki perkembangan kognitif-akademis rata-rata dan di atasnya. Guru cenderung mengabaikan siswa yang perkembangan kognitif-akademisnya di bawah rata-rata atau mengalami kesulitan belajar. Partisipan menuturkan, ketika saya ingin melayani siswa yang mengalami kesulitan belajar, banyak guru yang memberikan saran seperti ini: "Iya jangan peduli, hiraukan saja gitu, jangan focus kesitu, karna kalo fokus ke situ nanti siswa yang lain ketinggalan, katanya itu lama biarin aja." Guru-guru itu berkata pada saya" (Cici).

Armstrong

menyimpulkan bahwa guru-guru pada umumnya, tidak terkecuali guru-guru Indonesia menderita penyakit disteachia (salah mengajar), penyakit ini mengandung tiga virus T, yaitu Teacher Talking Time, Task Analysis, dan Tracking" (Chatib, 2015: 111). Teacher Talking Time dimaknai sebagai virus verbalisme akut yang menyebabkan guru selalu mengedepankan metode ceramah. Task Analysis merupakan virus yang menyebabkan konten pembelajaran menjadi sempit, tidak kontekstual, asing bagi pengalaman eksistensial siswa. Selanjutnya Tracking, virus ini menggerogoti paradigma berpikir guru bahwa kecerdasan seseorang hanya bisa diukur dari kemampuan kognitif-akademik saja yang teruji oleh tes yang telah distandarisasi. Kastanisasi kemampuan kognitif siswa itulah Tracking.

Mengacu pada pendapat Armstrong, dalam penelitian ini masih ditemukan guru yang menilai kepribadian siswa hanya pada nilai kognitif-akademisnya, kastanisasi manusia. Di saat guru mengabaikan siswa yang berkesulitan belajar, maka tidak terjadi iklim moral yang memiliki nuansa kepeduliaan, kehangatan, dan kekeluargaan. Sedangkan menurut Noddings (2003), iklim moral adalah situasi/kondisi dimana hubungan kepedulian dapat berkembang, bukan hanya upaya pendidik mengajari anak didiknya tentang perilaku baik, tapi juga upaya pendidik menjadi tauladan bagi anak didiknya. Tugas penting pendidik dalam lingkungan moral itu adalah menghargai 
berbagai bakat manusi anak didiknya, namun usaha ini harus dilakukan oleh pendidik dan anak didiknya. Setelah pendidik memiliki kepedulian kemudian pendidik harus mempunya kompetensi, untuk memenuhi kebutuhan kepedulian tadi, bukan hanya sikap ramah yang tidak jelas, untuk merespon secara afektif setelah mendengarkan berbagai kebutuhan siswa, maka guru harus menjadi pelajar seumur hidup.

Mengacu pada pendapat Noddings, dapat disimpulkan bahwa guru sebagai agensi moral harus memiliki hubungan interpersonal yang baik dengan semua orang, terutama siswa mereka. Karena sejatinya guru memiliki tanggung jawab moral untuk mengantarkan siswa mereka menuju kedewasaan berpikir dan berindak, memiliki akhlak mulia, dan mampu memecahkan masalah kehidupannya secara mandiri. Dalam hal ini, guru harus menciptakan iklim moral berbasis pendekatan kehangatan, persahabatan dan kekeluargaan. Tentu saja situasi problematis yang terungkap pada penelitian ini tidak seharusnya terjadi.

Pembahasan terakhir tentang tindakan moral. Ada beberapa faktor yang memengaruhi tindakan moral yaitu Kognitif, emosi, kepribadian, dan situasional. Menurut Blasi (1983) penalaran moral hanyalah predicator sederhana dari prilaku moral. Menurutnya diperlukan faktor lain supaya penalaran moral tersebut dapat berpengaruh pada prilaku moral. Dalam kata lain penalaran muncul setelah reaksi emosi. Emosi moral merupakan faktor penting dalam menjelaskan prilaku moral, emosi moral merupakan sesuatu yang berhubungan dengan kepentingan pribadi atau kesejahteraan masyarakat secara keseluruhan (Haidt, 2003). Emosi moral merupakan embodied moralty, yang berarti moralitas yang berhubungan dengan tubuh atau dikendalikan oleh tubuh. Jadi sala satu tanda bahwa suatu nilai moral sudah menyatu dengan tubuh adalah kita merasakan suatu emositer tentu ketika berhadapan dengan suatu perilaku atau peristiwa yang berhubungan dengan niai moral tersebut, contohnya kita merasa tidak nyaman ketika belum menunaikan salat atau melihat orang lain membuang sampah sembarangan (Q.S. al-Isra: 36).

Kepribadian juga merupakan faktor penting di dalam pembentukan prilaku moral (Blasi, 1983). Motivasi moral, karakter moral, dan kesadaran moral adalah faktor-faktor yang juga mempengaruhi pembentukan prilaku moral (Rest, 1983).

Selain faktor-faktor personal seperti yang sudah dijelaskan sebelumnya, prilaku moral juga dipengaruhi oleh faktor situasional. Faktor konteks penting dalam proses perubahan keyakinan spiritual seseorang (Rambo, 1995) yang dimaksud konteks adalah lingkungan sosial, kultural, keagamaan, dan personal, baik bersifat mikro maupun makro. Konteks dengan karakteristik berbeda akan menimbulkan prilaku berbeda Contohnya, keluarga menerapkan budaya Barat yang sekuler maka keluarga yang religius pun akan memberikan respons berbeda dengan keluarga sekuler.

Kerangka teori tindakan moral berasal dari Thomas Lickona yang 
mengkritik pemikiran Kohlberg yang hanya terpatok pada penalaran moral. Menurut Lickona, pemahaman dan perasaan moral akan membantu arah tindakan yang memiliki relevansi moral. Tindakan harus dilakukan secara konsisten berkelanjutan dan terinternalisasi dalam kehidupan sehari-hari hingga masa lanjut usia. Komponen tindakan moral adalah kompetensi moral, keinginan, dan kebiasaan. Kompetensi artinya kemampuan yang dimiliki untuk mengaplikasikan keputusan dan perasaan moral ke dalam aksi moral yang dilakukannya. Keinginan artinya kemampuan seseorang untuk melakukan segala sesuatu yang diinginkannya sesuai dengan nilai moral yang berlaku. Kebiasaan di sini yakni kebiasaan melakukan segala sesuatu sejalan dengan nilai dan norma yang berlaku, baik secara universal maupun berbasis kearifan lokal (Abidin, 2012).

Lebih luas lagi, Pasupathi \& Wainryb (2010) dalam artikelnya yang berjudul Developing Moral Agency Through Narrative menjelaskan bahwa sebenarnya, satu unsur agensi moral bagi individu mungkin terbukti dalam kecenderungannya untuk mempertimbangkan besar atau kecilnya relevansi moral dari tindakannya. Pertimbangan mengenai besarnya relevansi moral dengan tindakan dapat menimbulkan motivasi untuk berbuat kebajikan, sedangkan pertimbangan mengenai kecilnya relevansi moral akan menimbulkan keraguan atau rasa iba untuk berbuat keburukan yang merugikan atau menyakiti orang lain. Dari beberapa kutipan tersebut dapat disimpulkan bahwa tindakan moral adalah "eksekusi final" dari agensi moral. Tanpa tindakan kebajikan, apalah artinya pemikiran dan perasaan sebagai agensi.

Mengacu pada semua temuan penelitian yang sudah dipaparkan di atas dapat disimpulkan bahwa pada esensinya profesi guru merupakan profesi yang mulia dan menjungjung tinggi nilai etika, karena guru mengemban misi untuk mencetak generasi bangsa yang lebih manusiawi. Terkait dengan hal tersebut, realitas yang guru geluti adalah pendidikan dalam konteks luas yaitu sebagai upaya memanusiakan manusia (humanisasi) dan dibangun melalui usaha sadar dan terencana untuk mengembangkan berbagai potensi manusia secara multidimensional, sehingga dapat menjadi manusia yang utuh dan ideal, bukan pendidikan dalam konteks sempit (pengajaran atau pelatihan).

Dalam mengemban misi kemanusiaan ini, guru hendaknya memahami secara mendalam identitas moral dalam diri. Menurut Hart (2005) identitas moral adalah konsepsi yang penting dalam kehidupan manusia, setidaknya karena dua alasan. Pertama, ia membantu memahami tidak hanya teladan moral, tetapi juga kasuskasus bencana moral. Kedua, ia adalah konsepsi yang menjembatani antara konsepsi filosofis mengenai kehidupan moral dan temuan empiris tertentu dari penelitian psikologis atau etika.

Mengacu pada pendapat Hart, identitas moral merupakan pondasi yang kuat untuk membangun kesadaran agensi moral dalam diri seorang guru. Identitas moral juga 
berfungsi sebagai kompas dalam menginterpretasi nilai-nilai moral secara kritis. Karena pada esensinya nilai-nilai moral dalam kehidupan manusia dapat mempengaruhi dan mendorong manusia untuk membentuk hidup yang suci dan menghasilkan kebaikan dan memberikan faedah kepada sesama manusia. Hal ini didasarkan bahwa ketika manusia tunduk dan patuh pada aturan-aturan moral, maka ia akan memiliki tanggung jawab moral yang menjadi identitasnya sebagai manusia (Blasi, 1999).

Identitas moral dan penghayatan nilai-nilai moral akan memperkuat kesadaran moral. Menurut Campbel (2003, 2008) sebagai agensi moral, guru harus memiliki tingkat kesadaran moral yang tinggi. Dalam hal ini, tingkat kesadaran tertanam ketika guru mengembangkan kapasitas untuk mengidentifikasi bagaimana nilainilai dan asas-asal moral serta etika dicontohkan melalui tindakan, ucapan, pengambilan putusan, dan niat guru sendiri. Hubungan seperti itu tercipta secara intelektual, emosi, intuitif, filosofis, praktik, dan eksperiensial ketika guru melakukan refleksi perseorangan dan diskusi kolektif bersama rekan sejawat perihal pekerjaan yang digeluti setiap hari. Lebih jauh lagi Campbel (2003) mengemukakan bahwa agensi moral merupakan hasil dari peran dan tanggung jawab profesional guru. Agensi moral diungkapkan dan dinyatakan dalam praktik sehari-hari guru yang memberi teladan, mengatur diri, mengajarkan moral, menghubungkan, menasihati, dan melibatkan diri. Agensi moral merupakan penyuluhan tentang kebajikan serta asas-asas moral dan etika yang terjalin melalui kerumitan-kerumitan kehidupan di ruang kelas dan sekolah.

Mengacu pada pendapat Campbel (2003), jelaslah betapa pentingnya membangun keyakinan pada guru bahwa dia memiliki kewajiban sebagai agensi moral yang digolongkan pada dua wilayah aktivitas, yaitu: 1) melakukan tindakan profesional secara etis seperti kearifan, kedisiplinan, altruistik, kooperatif, visioner, tanggung jawab, dan integritas tinggi pada pekerjaan; dan 2) mengajarkan nilai-nilai moral dengan pendekatan pendidikan karakter seperti kejujuran, keadilan, keberanian, cinta tanah air, sabar, empati dan banyak lagi. Tujuan dari pendidikan karakter adalah membentuk kepribadian siswa agar memiliki kualitas karakter moral maupun karakter kinerja yang baik. Karakter moral dapat dimaknai sebagai kapasitas atau kekuatan untuk melakukan kebaikan di mana pun dan kapan pun, sedangkan karakter kinerja dapat dimaknai sebagai kapasitas atau kekuatan untuk melakukan yang terbaik dan penuh integritas agar dapat mencapai sebuah tujuan hidup dengan baik (Davidson, Khmelkov, \& Lickona, 2010).

Untuk melakukan kewajiban tersebut, guru harus menjadi teladan yang baik bagi semua orang, baik bagi siswa, keluarga siswa, rekan guru, kepala sekolah, maupun masyarakat luas. Vargas (2001) dalam sebuah penelitian tentang perkembangan moral guru dan etika profesional, mencatat bahwa perilaku, sikap, nilai, dan prioritas guru merupakan faktor paling kuat 
dalam membangun keteladan bagi siswa dan juga dalam mentransmisikan nilai-nilai kebajikan pada siswa. Sejalan dengan temuan Vargas, Ki Hajar Dewantara seorang tokoh pendidikan di Indonesia mengungkapkan konsep "trilogi kepemimpinan" dalam konteks pendidikan. Trilogi kepemimpinan merupakan gambaran guru sebagai pemimpin dalam dunia pendidikan yang harus memiliki tiga karakter. Pertama, guru harus mampu menjadi teladan di depan murid; kedua, guru harus membangun semangat dan kepedulian di tengah murid; dan ketiga, guru harus mampu memberi bimbingan dengan cara: a) mengarahkan (menuntun perilaku siswa) agar berbudi luhur, dan b) memberi kepercayaan pada murid untuk menemukan potensi atau kodrat alamnya (Ibrahim \& Hendriani, 2017).

\section{PENUTUP}

Penelitian ini menyajikan deskripsi representasi kesadaran agensi moral mahasiswa S2 prodi Pedagogik Sekolah Pascasarjana UPI pada fenomena profesi guru. Agensi moral pada penelitian ini terdiri atas identitas moral, sensitivitas moral, dan tindakan moral. Penelitian ini meyimpulkan bahwa mahasiswa prodo Pedagogik memaknai guru secara esensial sebagai pekerjaan yang memiliki tanggung jawab moral, dan itu berlaku di mana pun guru berada, tidak hanya terpaku di lingkungan sekolah. Tanggung jawab moral terkait dengan masa depan peserta didik secara khusus dan pendidikan secara umum. Selain itu, menjadi guru haruslah mengabdi pada negeri, jangan mengharapkan imbalan di awal dan jangan terusterusan mempermasalahkan tunjangan kesejahteraan. Hal ini tidak etis. Bagi para partisipan, pekerjaan guru adalah kepuasan batin. Di saat melihat peserta didik berubah menjadi lebih baik, guru merasa sangat senang. Partisipan juga menyatakan bahwa menjadi guru adalah pahlawan tanpa tanda jasa. Melalui pembangunan identitas moral, partisipan mampu mengidentifikasi beberapa situasi problematis yang menggejala di dunia pendidikan, sehingga dengan penuh kesadaran partisipan mampu melakukan tindakan moral untuk mengemansipasi kehidupan menjadi lebih baik.

Penelitian ini masih berupa studi fenomenologis yang hanya merepresentasikan pengalaman partisipan pada fenomena profesi guru. Penelitian ini tidak menggambarkan profil kesadaran agensi moral semua mahasiswa pascasarjana UPI. Dan segala bentuk temuan pada penelitian ini, baik yang positif maupun yang negatif tidak menggambarkan profil guru secara umum, hanya beberapa guru saja dan tentunya dalam pengalaman eksistensial partisipan. Penelitian ke depan diharapkan mampu menghasilkan model pendidikan etika profesi guru berbasis agensi moral.

\section{UCAPAN TERIMA KASIH}

Tulisan ini dapat terselesaikan atas bantuan dari berbagai pihak. Ucapan terima kasih disampaikan terutama kepada dewan redaksi Jurnal Pendidikan Karakter, terutama ketua, yang telah sudi menerima draf 
tulisan ini hingga akhirnya dapat dimuat pada edisi sekarang ini.

\section{DAFTAR PUSTAKA}

Abidin, Y. (2012). Pembelajaran membaca berbasis pendidikan karakter. Bandung: PT. Refika Aditama.

Aquino, K., \& Reed II, A. (2002). The self-importance of moral identity. Journal of personality and social psychology, 83(6), 1423.

Armstrong, T. (2010). Multiple intelligences in the classroom. Virginia, USA: ASCD.

Ball, S.J. (2003). The teacher's soul and the terrors of performativity. Journal of Educational Policy, 18(2), 215-228.

DOI: $10.1080 / 0268093022000$ 043065.

Bandura, A. (2002). Selective moral disengagement in the exercise of moral agency. Journal of Moral Education, 31(2), 101119.

DOI: 10.1080/0305724022014322.

Barrett, A. M. (2008). Capturing the differance: Primary school teacher identity in Tanzania. International Journal of Educational Development, 28(5), 496-507. DOI: 10.1016/j.ijedudev.2007.09.00 5.

Beijaard, D., Paulien, C. M. \& Verloop, N. (2004). Reconsidering research on teachers' profesional identity. Teaching and Teacher Education, 20(2), 107-28.

DOI:

$\underline{10.1016 / \text { j.tate. } 2003.07 .001 .}$

Bergman, R. (2004). Identity as motivation: Toward a theory of the moral self. Moral Development, Self, and Identity, 2, A6. 21-46. Retrieved from https://books.google.co.id/book s?hl=id\&lr=\&id=q054AgAAQ BAJ\&oi=fnd\&pg=PA21\&ots $=$ eiwpraZ6fF\&sig=hgxxoskT6V tM7DKsf223ZNUATRo\&redir esc $=\mathrm{y} \# \mathrm{v}=$ onepage $\& \mathrm{q} \& \mathrm{f}=$ false

Berlin, I. (2014). Freedom and its betrayal: Six enemies of human liberty. Princeton, USA: Princeton University Press. DOI: $10.2307 /$ j.ctv6zddb3.

Blasi, A. (1983). Moral cognition and moral action: A theoretical perspective. Developmental Review, 3(2), 178-210. DOI: $\underline{10.1016 / 0273-2297(83) 90029-}$ 1 .

Blasi, A. (1999). 12a Comment: Caring About Morality: The Development of Moral Motivation in NunnerWinkler's Work. Individual Development from 3 to 12: Findings from the Munich Longitudinal Study, 291.

Campbell, E. (2003). The Ethical Teacher. Maidenhead, Berkshire (UK): Open University Press. 
Campbell, E. (2008). Teaching ethically as a moral condition of professionalism. In Nucci, L \& Narvaez, D (eds.). Handbook of Moral and Character Education (pp. 601617). London, New York: Routledge.

Chatib, M. (2015). Sekolahnya manusia: Sekolah berbasis multiple intelligences di Indonesia. Bandung: PT Mizan Pustaka.

Codd, J. (2005). Teachers as 'managed professionals' in the global education industry: The New Zealand experience. Educational Review, 57(2), 193-206. DOI: 10.1080/001319104200030836 9.

Colnerud, G. (2006). Teacher ethics as a research problem: Syntheses achieved and new issues. Teachers and Teaching: Theory and Practice, 12(3), 365-385.

DOI: 10.1080/13450600500467704.

Corbin, J., \& Strauss, A. (2008). Grounded theory research: Procedures, canons and evaluative criteria. Zeitschrift für Soziologie, 19(6), 418-427. DOI:

https://doi.org/10.1007/BF0098 8593.

Davidson, M. L., Khmelkov, V., \& Lickona, T. (2010). The power of character: Needed for, and developed from, teaching and learning. In T. Lovat, R. Toomey, \& N. Clement (Eds.).
International research handbook on values education and student wellbeing Dordrecht: Springer, 427-454. 10.1007/978-90-481-86754_26.

Day, C., Kington, A., Stobart, G., \& Sammons, P. (2006). The personal and professional selves of teachers: Stable and unstable identities. British Educational Research Journal, 32(4), 601-616. DOI: 10.1080/01411920600775316.

Egan, E. A., Parsi, K., \& Ramirez, C. (2004). Comparing ethics education in medicine and law: Combining the best of both worlds. Annals of Health Law, 13, 303-325. Retrieved from https://lawecommons.luc.edu/c gi/viewcontent.cgi? article $=123$ $\underline{4 \& \text { context=annals }}$.

Fazio, R. H. (1987). Self-perception theory: A current perspective. In Social Influence: The Ontario Symposium, 5, 129150. Retrieved from https://www.taylorfrancis.com/ books/9781315802121/chapter s/10.4324/9781315802121-12.

Freire, P. (2001). Pedagogy of the Heart. New York: Continum.

Freire, P. (2008). Pendidikan kaum tertindas (Terj. Oleh Tim Redaksi LP3ES. Trans). Jakarta: LP3ES.

Haidt, J. (2003). The moral emotions. Handbook of Affective Sciences (pp. 852- 
870). Oxford, New York: Oxford University Press.

Hardy, S. A., \& Carlo, G. (2011). Moral identity: What is it, how does it develop, and is it linked to moral action? Child Development Perspectives, 5(3), 212-218. DOI: $10.1111 / \mathrm{j} .1750-$ 8606.2011.00189.x.

Hargreaves, A., \& Goodson, I. (2006). Educational change over time? The sustainability and nonsustainability of three decades of secondary school change and continuity. Educational Administration Quarterly, 42(1), 3-41. DOI: $10.1177 / 0013161 X 05277975$.

Hart, D. (2005). The development of moral identity. In G. Carlo \& C. P. Edwards (Eds.), Vol. 51 of the Nebraska Symposium on Motivation. Moral Motivation through the Life Span (pp. 165-196). University of Nebraska Press.

Ibrahim, T., \& Hendriani, A. (2017). Kajian reflektif tentang etika guru dalam perspektif Ki Hajar Dewantara berbalut filsafat moral utilitarianisme. NATURALISTIC: Jurnal Kajian Penelitian Pendidikan dan Pembelajaran, 1(2), 135145. DOI: $\underline{10.35568 / \text { naturalistic.v1i2.12. }}$.

Jahan, N., \& Islam, M. S. (2014). Ethical issues in university teaching: Some selected university teachers' perceptions and practices. Educational Quest: An International
Journal of Education and Applied Social Sciences, 5(2), 93-101. DOI: 10.5958/22307311.2014.00001.4.

Lasky, S. (2005). A sociocultural approach to understanding teacher identity, agency and professional vulnerability in a context of secondary school reform. Teaching and Teacher Education, 21(8), 899-916. DOI: 10.1016/j.tate.2005.06.003.

Menter, I. (2008). Tradition, culture and identity in the reform of teachers' work in Scotland and England: Some methodological considerations. Pedagogy, Culture \& Society, 16(1), 5769. DOI: $10.1080 / 14681360701877784$.

Narvaez, D., \& Lapsley, D. (2014). Becoming a moral personMoral development and moral character education as a result of social interactions. In Empirically informed ethics: Morality between facts and norms (pp. 227-238). Springer International Publishing.

Noddings, N. (2003). Happiness and education. Cambridge University Press.

Pasupathi, M., \& Wainryb, C. (2010). Developing moral agency through narrative. Human Development, 53(2), 55-80. DOI: $\underline{10.1159 / 000288208 .}$.

Plasschaert, A., Boyd, M., Andrieu, S., Basker, R., Beltran, R. J., 
Blasi, G., ... \& Kerschbaum, T. (2002). 1.3 Development of professional competences. European Journal of Dental Education, 6(s3), 33-44. DOI: 10.1034/j.1600-0579.6.s3.5.x.

Rambo, E. (1995). Conceiving best outcomes within a theory of utility maximization: a culturelevel critique. Sociological Theory, 13(2), 145-162. DOI: $10.2307 / 202158$.

Rest, J. R. (1983). Morality. Handbook of Child Psychology, 3, 556-629. New York: Wiley.

Rest, J. R., \& Narváez, D. (Eds.). (1994). Moral development in the professions: Psychology and applied ethics. New York: Lawrence Erlbaum Associates, Inc.

Smetana, J.G. (1982). Concepts of self and morality: Women's reasoning about abortion. New York: Praeger.

Sockett, H., \& LePage, P. (2002). The missing language of the classroom. Teaching and Teacher Education, 18(2), 159171. DOI: $10.1016 / \mathrm{S} 0742-$ 051X(01)00061-0.

Strike, K. A., \& Ternasky, P. L. (1995). Ethics for profesionals in education: Perspectives for preparation and practice. New York: Teachers College Press.

Taylor, C. (1989). Sources of the self: The making of the modern identity. Cambridge, MA: Harvard University Press.

Turiel, E., Hildebrandt, C., \& Wainryb, C. (1991). Judging social issues: Difficulties, inconsistencies, and consistencies. Monographs of the Society for Research in Child Development, 56(2), 1116. DOI: $10.2307 / 1166056$.

Vargas, R.A.C. (2001). The moral profession: A study of moral development and profesional ethics of faculty. Unpublished PhD Dissertation. Texas: University of Texas at Austin.. 